\title{
Human Capital and Multifaceted Innovation: Evidence from the Lahore Knitwear Cluster in Pakistan
}

\section{Fahd Rehman*}

\begin{abstract}
Clusters have the potential to grow, but their potential in Pakistan is rarely analyzed and examined. This study examines the knitwear cluster of Lahore in general and the performance of enterprises in particular. Most of the literature on clusters in Pakistan has not looked at the characteristics of the individual enterprises that play a pivotal role in cluster development. Using primary data collected from 59 finished-knitwear producers in Lahore, this study assesses the role of human capital in acquiring multifaceted innovations. We find that general human capital acquired by schooling and specific human capital acquired through operational experience is associated with the size of the enterprise. Additionally, specific human capital acquired through operational and marketing experience is strongly correlated with improved marketing channels.
\end{abstract}

Keywords: Clusters, human capital, schooling, multifaceted, Pakistan.

JEL Classification: E24.

\section{Introduction}

The promotion of industries has been a major agenda of developing countries, and Pakistan is not an exception. Specifically, labor-intensive industries, such as knitwear, woven products, footwear, toys, and plastic parts, create substantial employment opportunities and play a pivotal role in reducing poverty (Sonobe \& Otsuka, 2006). Pakistan is a major Asian player in the garments export market and the garments sector is one of the largest sources of low-cost employment creation (Memon, 2010). The advent of the World Trade Organization (WTO) regime in 2005 has intensified competition in Pakistan in general and in the knitwear industry in particular. Such intense competition in the international apparel industry has compelled producers to reduce product prices, increase quality, and significantly shorten delivery times (Saheed, 2011).

\footnotetext{
* Doctoral Candidate, School of Business, University of New South Wales, Canberra, Australia.
} 
The knitwear cluster of Lahore is not an exception and faces the challenges of quality and price in the international market. Recently, Lahore's knitwear enterprises have also been subject to gas and electricity rate hikes and load shedding. These international and local challenges have forced these enterprises to cut their costs through various innovations such as improved production organization and enhanced production efficiency, and aggressive marketing strategies in search of higher product prices. ${ }^{1}$ This simply means that knitwear enterprises face pressure to innovate under intensified competition. We intend to investigate empirically the characteristics of those innovative producers who adopt these innovations under such competitive conditions.

There are a variety of concepts and definitions of industrial clusters as depicted in the literature on business economics, innovation studies, and development economics. The literature broadly conceives of clusters in a geographical and sectoral sense. For instance, Porter (1990) defines a cluster as a geographic concentration of interconnected companies and institutions in a particular field. Schmitz and Nadvi (1999) and Schmitz (1995) define a cluster as a sectoral and geographical concentration of firms. Rosenfield (1995) defines a cluster as a loose, geographically bounded agglomeration of similar, related firms. Sonobe and Otsuka (2006) define an industrial cluster as a geographical concentration or localization of enterprises producing similar or closely related products in a small area. For this study, we will use the definition advanced by Sonobe and Otsuka (2006).

The reduction in transaction costs among enterprises in an industrial cluster is also significant (Sonobe \& Otsuka, 2006). Sonobe and Otsuka (2006) further argue that transaction costs rather than transportation costs in industrial clusters enhance the development of the division of labor and facilitate the transaction of intermediate goods and services among enterprises. They term the industrial cluster an "artificially created" community that reduces transaction costs. However, the literature on economic geography often points out that specialization and the division of labor among enterprises occurs because of low transportation costs due to the geographical concentration of firms in a small area (Krugman, 1991). Finally, Sonobe and Otsuka (2006) argue particularly that, apart from the division of labor between manufacturers and parts suppliers, the division of labor between manufacturers and merchants is also important in an industrial cluster because clusters attract traders since they provide wider choices of products and producers.

\footnotetext{
${ }^{1}$ The chairperson of the Pakistan Hosiery Manufacturers Association (PHMA) Lahore mentioned this point.
} 
Although innovations play a significant role in industrial clusters, with the term "innovation" broadly defined. Schumpeter (1912) argues that industries develop through a series of innovations and imitations, where innovation is nothing but a new combination of productive resources to increase profit. Schumpeterian innovations encompass the introduction of a new product or a new quality of product; new production methods and organization, new markets and the discovery of new materials and entrepreneurs are the carriers of such innovations.

Similarly, the concept of "multifaceted innovations", which is closely related to Schumpeterian innovations, has been introduced by Sonobe and Otsuka $(2006)$ based on the findings of eight cluster studies on garments, motorcycles, machine tools, and low-voltage electrical appliances in East Asia. They propose an endogenous model of industrial development based on these findings. According to their model, a cluster usually passes through three distinct stages: (i) an initiation stage, (ii) quantity expansion stage, and (iii) quality improvement stage (Appendix 3).

In the initiation stage of cluster development, a few innovative producers imitate imported products directly or indirectly through a trialand-error process and start manufacturing in the suburbs or vicinity of a large city. If the industry is labor-intensive, such as garments or footwear where marketing and cheap labor is key to success, it will be led by merchants. On the other hand, if the product is complicated and technical, the industry will be led by engineers. In the initiation stage, the market for intermediate inputs and components may not be available due to the small scale of production. So, the founding enterprise will have to procure all the materials needed and sell the final product directly to the consumer.

In the quantity expansion stage, the product, production process, and marketing channels are standardized and can be easily imitated. Then, new entrants from various fields in general imitate production on a large scale and former workers from existing pioneer enterprises, i.e., spin-offs, enter the field specifically, contributing to the spontaneous formation of the industrial cluster. The division and specialization of labor develops between manufacturers and parts suppliers and between manufacturers and traders. In the quantity expansion stage, entrepreneurs possess a mixed level of education and produce low-quality products with negligible productivity gains. The new entrants create an excess supply of the cluster's product through imitation, which reduces the innovators' profit by reducing the product price. This can discourage further innovation by the innovators. 
In the transition from the quantity expansion stage to the quality improvement stage, the fortunate presence of agglomeration economies, the variety of skilled human resources, and knowledge spillovers reduces innovation costs and provides incentive to producers to innovate. The quality improvement stage is characterized partly by the productivity gains of the enterprises due to the exit of inefficient enterprises and partly by the adoption of improved production methods and the high-quality products of the surviving enterprises. Another feature of this stage is the emergence of large enterprises that produce high-quality differentiated products and that start selling or exporting to foreign buyers, and thus directly enter the global value chain as shown in Appendix 1.

A review of the existing literature shows the presence of multifaceted innovations in various clusters. For instance, the major innovation in China's low-voltage electrical appliances cluster has been the introduction of quality inspection and own branding (Sonobe, $\mathrm{Hu}$, \& Otsuka, 2004). Similarly, enterprises in Ethiopia's footwear cluster increased the direct procurement of raw materials and direct product sales through the use of brand names (Sonobe, Akoten, \& Otsuka, 2009). Enterprises adopted different marketing channels in Agra's footwear cluster to stabilize their orders and command higher product prices (Knorringa, 1999). Shoe manufacturers in the Sinos Valley in Brazil adopted major innovations in marketing through branding to other parts of Brazil and neighboring countries (Bazan \& Navas-Aleman, 2004). In Vietnam's knitwear cluster, village enterprises adopted innovations in entry into the export market and vertical integration (Nam, Sonobe, \& Otsuka, 2010).

Despite the general significance of human capital, the existing literature seldom tries to identify which producers contribute to cluster development (Schmitz, 1995; Nadvi, 1999; Schmitz \& Nadvi, 1999; Schmitz, 2006). A notable exception are Sonobe and Otsuka (2006), who empirically examine the role of human capital in the development process of industrial clusters. The literature on successful industrial clusters in East Asia examined by Sonobe, $\mathrm{Hu}$, and Otsuka (2002) and Sonobe and Otsuka (2006) and on African countries by Akoten and Otsuka (2007) confirms that human capital plays a pivotal role in cluster and industrial development. They argue that entrepreneurs cannot innovate if high-quality human resources are lacking, because in the absence of human capital, the cost of innovation is too high. 
The concept of upgrading is defined in the literature as the possibility that developing countries' suppliers will "move up the value chain" or as the "innovation to increase value added" (Giuliani, Pietrobelli, \& Rabellotti, 2005). This definition demonstrates that upgrading involves innovation. The concept of upgrading entails four categories developed by Humphrey and Schmitz (2002): (i) process upgrading (achieving the more efficient transformation of inputs into outputs); (ii) product upgrading (moving into higher value-added products); (iii) functional upgrading (acquiring new functions such as branding, marketing, and designing; and (iv) inter-sectoral/chain upgrading (applying the competence acquired by one function of a chain and using it in a different sector/chain).

To our knowledge, only a few cluster studies have been conducted on the surgical instruments cluster in Sialkot (Nadvi, 1999; Thompson, 2005) and the cutlery cluster in Wazirabad (Nadvi, 1996). While these studies examine how clustered enterprises respond to international challenges and evaluate their growth trajectory, they do not focus on the characteristics of entrepreneurs and the performance of enterprises. Although the importance of multifaceted innovations is fully explored in the literature, solid empirical studies have seldom been carried out to examine the characteristics of innovative entrepreneurs in Pakistan. Arif and Sonobe (2012) examine the factors affecting the performance of enterprises in Sargodha's electrical fittings cluster, which caters to domestic needs. Interestingly, there is limited knowledge about the innovative entrepreneurs operating in Pakistan's industrial clusters and it has not yet been fully explored. Moreover, understanding the upgrading strategies of enterprises is important; as Tokatli (2007) argues, knowing enterprises' strategies helps one better understand an industry.

The next section presents an overview of the knitwear industry in Pakistan and the Lahore cluster. Section 3 puts forward a series of testable hypotheses, and Section 4 describes the data collection process and statistics used. Section 5 presents the study's results, and Section 6 brings out the conclusion, limitations, and scope for future research.

\section{Overview of Pakistan's Knitwear Industry and Lahore Cluster}

The knitwear industry is Pakistan's highest value-added sector (Memon, 2010) . The share of knitwear in the country's total exports was 9.3 percent in 2010/11, hovering around 8-12 percent from 1995 to 2011 (Table 1). Knitwear exports increased from USD 688.5 million in 1995 to USD 2,305.55 million in 2011. It is a high value sector, earning valuable 
foreign exchange per kilogram of cotton converted in finished garments for the country as reported by the Pakistan Hosiery Manufacturers Association (PHMA, 2011).

Table 1: Exports and knitwear industry's share of total exports

\begin{tabular}{cccc}
\hline Year & $\begin{array}{c}\text { Total exports } \\
\text { (USD million) }\end{array}$ & $\begin{array}{c}\text { Knitwear exports } \\
\text { (USD million) }\end{array}$ & $\begin{array}{c}\text { Knitwear share of } \\
\text { total exports (\%) }\end{array}$ \\
\hline 1995 & $8,137.20$ & 688.50 & 8.46 \\
1996 & $8,707.10$ & 703.40 & 8.08 \\
1997 & $8,320.30$ & 688.90 & 8.28 \\
1998 & $8,627.70$ & 696.70 & 8.08 \\
1999 & $7,779.30$ & 742.20 & 9.54 \\
2000 & $8,568.60$ & 886.70 & 10.35 \\
2001 & $9,201.60$ & 911.40 & 9.90 \\
2002 & $9,134.60$ & 845.90 & 9.26 \\
2003 & $11,160.20$ & $1,146.70$ & 10.27 \\
2004 & $12,313.30$ & $1,458.70$ & 11.85 \\
2005 & $14,391.10$ & $1,635.00$ & 11.36 \\
2006 & $16,451.20$ & $1,751.50$ & 10.65 \\
2007 & $16,976.20$ & $1,798.50$ & 10.59 \\
2008 & $19,052.30$ & $1,732.10$ & 9.09 \\
2009 & $17,688.00$ & $1,714.90$ & 9.70 \\
2010 & $19,290.00$ & $1,765.00$ & 9.15 \\
2011 & $24,810.42$ & $2,305.55$ & 9.29 \\
\hline
\end{tabular}

Source: Trade Development Authority of Pakistan (2011).

The knitwear industry is concentrated mainly in four cities: Karachi, Lahore, Faisalabad, and Sialkot, among which Lahore's knitwear cluster is considered the "home of knitwear" (Memon, 2010). Our study site is, therefore, Lahore, the capital of the province of Punjab, and Pakistan's second largest, industrialized city, with a total land area of $404 \mathrm{~km}^{2}$ (UNIDO, 2006). Lahore's knitwear enterprises are located in suburban areas across the city, but most are located around Ferozepur Road, Kot Lakhpat Industrial Estate, and along the Defence road within a radius of $10 \mathrm{~km}^{2}$.

The knitwear cluster of Lahore started to evolve around 30 years ago and is still growing (UNIDO, 2006). The cluster was initiated through small enterprises and mainly catered to low value-added products. In the beginning, garments were sold in the domestic market, and so the quality 
requirements were not high and the cluster employed outdated machinery (Rana \& Khan, 2009). However, the cluster started exporting knitwear garments in 1987 through the Ammar textile company; the enterprise brought many international labels to Pakistan and the cluster connected to medium value-added products (Rana \& Khan, 2009). The major advancement in the Lahore knitwear cluster took place during the early 1990s when, for the first time, automatic and computerized knitting machines were introduced (UNIDO, 2006).

The cluster began to expand and flourish in 1995 owing primarily to endowments such as the availability of good-quality raw material, machinery parts suppliers, surplus labor, and different government incentives including an export refinance facility, duty drawbacks, and soft loans from commercial banks (UNIDO, 2006).

Another contributing factor in its growth related to the policies pursued by successive governments during the 1990s and early 2000s. The government pursued various schemes, including an export refinance facility, sales tax refunds, duty drawbacks, and soft loans introduced by commercial banks (UNIDO, 2006). Finally, growth was also catalyzed by external factors, i.e., the Multi-Fibre Agreement. This gave enterprises access to the North American market, and local manufacturers enjoyed huge margins and stable orders and huge margins as global buyers were bound to purchase from them until 2004 (Rana \& Khan, 2009). The cluster expanded and grew rapidly by the turn of the century as a result of the stable orders and prices from global buyers (Rana \& Khan, 2009).

The cluster experienced an external shock in 2005 with the advent of the WTO regime. The quota facility under the Multi-Fibre Agreement expired, and the enterprises were exposed to fluctuating international markets. A section of manufacturers invested in the latest machinery because of low interest rates during 2001-05 on the presumption that they would acquire stable orders even under the quota-free regime. However, most of the leveraged enterprises closed down after 2005 owing to the inefficiencies that arose out of the lack of management and training of the labor force and organization methods (Rana \& Khan, 2009). The record of the Pakistan Hosiery Manufacturers' Association (PHMA) shows that 47 units closed by November 2007 (there were 126 exporters in 2005); 15 of the closed enterprises were vertically integrated ones.

The closure of these vertically integrated enterprises paved the way for "cut to pack" units, which carried out operations from cutting to 
packing, i.e., garment making enterprises. As new entrants, they were smaller and outsourced the fabric production. The process flows of vertically integrated and "cut to pack" enterprises are depicted in Appendix 1. The presence of these vertically integrated enterprises was the result of a lack of development among knitwear fabric suppliers in the late 1980s and the unwillingness of suppliers to invest in knitting and dyeing at the time (Rana \& Khan, 2009). This also confirms that, in the initiation stage, entrepreneurs have to procure and sell the final product directly to their buyers and operate vertically integrated plants.

There are numerous cluster actors, including suppliers of raw materials (yarn/fabric), knitting machines/parts, dyes and chemicals, electrical parts of knitting machines, buttons/zips, and packing materials, that support exporting enterprises (UNIDO, 2006). The cluster produces mainly men's products (polo t-shirts, hoods, sweatshirts, crewnecks, and jackets) in large quantities, while similar women's and children's garments are produced in small quantities along with trousers and shorts. The cluster also produces and exports various kinds of sports garments, dresses, and medical socks.

Our survey shows that the value of annual exports from the cluster was estimated at around USD 430 million in 2010/11 (Table 2). There were around 85 finished garment-exporting enterprises operating in the Lahore cluster along with 190 subcontractors that either catered to the domestic market or to the exporting enterprises. Of the exporting enterprises, 25 were vertically integrated while the rest were "cut to pack" units. The oldest existing enterprise in the cluster was established in 1987. The cluster's competitive advantage was the presence of high-quality raw material and the availability of cheap labor. The key challenge it faced was frequent electricity and gas load shedding, which was making it difficult to meet its strict deadlines. The details of the cluster are given in Table 2. 
Table 2: Summary of Lahore knitwear cluster, 2011

\begin{tabular}{ll}
\hline Exports & USD 430 million approx. \\
Cluster structure & 85 exporters \\
& 190 subcontractors \\
Direct employment & 35,000 approx. \\
Indirect employment & 10,000 approx. \\
Main markets & US, EU \\
Competitive advantage & High-quality raw material and cheap \\
Key challenge & labor \\
\hline
\end{tabular}

Source: 2011 cluster survey.

\section{Testable Hypotheses}

Based on the evidence above, the Lahore knitwear cluster has already passed through the initial and quantity expansion stages and is now transitioning to the qualitative improvement stage. The emerging literature on cluster-based industrial development across Asia and Africa shows that quality improvement is possible through the introduction of multifaceted innovations in enterprise size, production organization, and improved marketing channels (Sonobe et al., 2009). All these multifaceted innovations are associated with both the generic and specific human capital of entrepreneurs.

General human capital is important because it improves the ability to decode and adopt new information (Becker 1962, 1993). Measuring human capital is difficult, but a suitable proxy used in the literature is the number of years of formal schooling-basically, a generic measure of human capital not specifically related to the business sector or production activities. Since information processing ability is important for the adoption of new ideas and technologies, human capital plays an important role in economic growth (Lucas 1988; Barro 1991; Mankiw, Romer, \& Weil, 1992), and, similarly, in cluster development (Sonobe \& Otsuka, 2006). Altenburg and Meyer-Stamer (1999) differentiate between the survival and growth of clusters in Africa through the presence of highly educated managers and engineers.

Specific human capital acquired by years of operation and marketing experience during the quantity expansion stage facilitates the transition from the quantity expansion stage to the quality improvement 
stage. Here, management experience plays an important role in adopting multifaceted innovation (Yamamura, Sonobe, \& Otsuka, 2003; Sonobe \& Otsuka, 2006; Nam et al., 2010). Specific human capital is attained through related trade, business, and specialized experience (Hackler \& Mayer, 2008). However, reliance on generic human capital usually underplays the significance of specific human capital, which is acquired through learning by doing (OECD, 2000).

After the cluster's formation and the presence of multifaceted innovations, highly educated entrepreneurs become the carriers of those innovations and play a significant role in expanding the size of enterprises (Sonobe et al., 2009). Hence, generic human capital measured by schooling and specific human capital measured by operation experience would be positively associated with enterprise size, and one could call it process upgrading. Thus, our first hypothesis is as follows:

Hypothesis 1: In an export-oriented knitwear cluster, general human capital acquired by schooling and specific human capital acquired by management is significantly associated with enterprise size.

Some capable producers export directly to global buyers, and thus directly connect to the global value chain. Additionally, the opening up of markets has increased the sourcing options of global buyers, who can now choose from a growing number of developing countries' producers. The number of sourcing countries for knitwear apparel and clothing (item code 61) to the US in 1995 were 139, rising to 157 in 2009 (United Nations Statistics Division, 2010). Similarly, the number of knitwear exporting countries (item code 61) to the EU-27 increased from 177 in 2000 to 185 in 2009 (United Nations Statistics Division, 2010).

From the standpoint of transaction costs, it is more likely that global buyers purchase directly from a small number of capable producers who can supply a large amount of quality products within short delivery times, than buying from a large number of small producers or buying through their local agents (Schmitz, 2006). One of our respondents confirmed that they competed with just five international competitors when a global buyer placed orders among the developing countries' suppliers. Similarly, entrepreneurs' marketing experience contributes toward improving the direct transactions of local enterprises with global buyers in the garments clusters of China and Japan (Sonobe \& Otsuka, 2006). Keeping in view these factors, local knitwear producers are encouraged to export directly to global buyers since direct exports command higher prices and stable export 
orders, and eliminate the intermediate channel of local agents and, hence, save on the agent's commission. Thus, specific human capital acquired though operational and marketing experience plays a significant role in improving the marketing channel and can easily be declared a form of functional upgrading. Marketing channels are depicted in Appendix 2. So, our second hypothesis is as follows:

Hypothesis 2: Superior operational experience along with superior marketing ability acquired through marketing experience is associated with improved marketing channels for enterprises.

\section{Data and Descriptive Statistics}

An enterprise-level survey was conducted from September to November 2011 to collect detailed financial and nonfinancial information on a sample of 59 finished knitwear manufacturing enterprises in Lahore. Since we only observe the surviving enterprises, there may have been a selection issue and we cannot carry out a Heckman selection because of the cross-sectional sample.

Although both the garments and socks producers fall into the knitwear sector, their production processes are quite different. There are four main stages in finished garment production: knitting, dyeing, cutting, and stitching. The standard method for knitting fabrics is to run a circular knitting machine loaded with yarn to produce fabric, while the standard method for making garments from fabric is to use an assembly line of sewing machines and operators. Sock production also follows four main stages: sock knitting, toe linking/over-locking, bleaching/dyeing, and finishing. As the process flows, the machinery and production of finished garments, socks, gloves, and sweaters is different, so the cluster survey focused on finished knitwear garments and omitted the others owing to their small population and different process details. The small sample size of 21 sock-manufacturing enterprises did not allow a regression analysis and comparison of results for finished garment producers.

Of a population of 85,81 enterprises were registered with the PHMA and four with the Pakistan Readymade Garments and Exporters Association (PRGMEA). Sixty enterprises produced finished knitwear garments, 21 produced socks, and two manufactured sweaters and gloves, respectively. One of the finished garments producing entrepreneurs refused to provide information. The total sample size was, therefore, 59. 
A structured and purpose-designed questionnaire was completed for each enterprise through direct interview, either with the entrepreneur or the general manager. Since we sought specific information on each enterprise's marketing channel, we approached key individuals in its merchandise department. It is important to mention here that an effort was made to examine the quality improvement stage of the cluster, and so data was collected from all leading finished garment producers. The information on entrepreneurs' years of schooling, age, marketing experience, years of operation, spin-offs, previous occupation, and family business was obtained from the 2011 cluster survey.

Table 3 presents data on the characteristics of the entrepreneurs in the sample. Their average number of years of schooling was 15.4. Entrepreneurs had an average of 2.3 years of marketing experience before having established their own enterprise. Similarly, the average number of years of operation of the sampled enterprises was 11.2. The number of spin off-entrepreneurs-workers in other enterprises-was 39, which was approximately 66 percent of the sample. Of the 59 entrepreneurs, 15 were merchants in knitwear garments, considered a merchant-led industry (Sonobe \& Otsuka, 2006). Therefore, the sample reflected a moderate percentage of their presence.

\section{Table 3: Characteristics of sample entrepreneurs before establishment} of enterprise

\begin{tabular}{ll}
\hline Average number of years of schooling & 15.4 \\
Years of marketing experience & 2.3 \\
Average number of years of operation & 11.2 \\
Average age of entrepreneurs in 2011 & 46.3 \\
Number of spin-off enterprises & 39 \\
Enterprises Led by Merchants (number) & 15 \\
Enterprises Led by Production executives (number) & 21 \\
Family business (number of enterprises) & 8 \\
Others (number of enterprises) & 15 \\
Total Number of enterprises & 59 \\
\hline
\end{tabular}

Source: 2011 cluster survey.

Most of the enterprises in the cluster were managed by sole entrepreneurs, while a few were managed by associations of persons. Approximately 40 and 30 percent of the entrepreneurs were executives and merchants, respectively, either in the existing enterprises or in those that 
had closed down. Moreover, 20 and 10 percent of the entrepreneurs had moved to this cluster through other businesses and family connections, respectively. Among the entrepreneurs, approximately 75 percent had graduated after 16 years of education, while 23 percent had completed 14 years (2011 cluster survey). This reflects a very high level of human capital in comparison with the existing literature on cluster development. Interestingly, 36 percent of the entrepreneurs had worked as production executives before setting up their own enterprise, and formed a dominant category in the sample. Around 14 percent had taken up the business from their parents, who had founded it. The cluster survey also showed that the sons of parents who had founded the firm were more likely to have acquired their higher education from abroad. Around 25 percent of the entrepreneurs became owners by moving in from other businesses through the existence of buying houses.

Table 4 shows the distribution of the marketing channels of the sample enterprises. The composition shows that around 15 percent of sample enterprises sold their products directly to global buyers located mainly in the US and European Union; 52 percent sold their products through buying houses located in Lahore. The respondents reported longterm relations with the buying houses, which may be termed "putting out" arrangements. Under these arrangements, merchants or "putters" give designing, marketing, and procurement instructions while the enterprises carry out the manufacturing. The putters bring samples to the local enterprises for replication, which reflects that the guidelines of global buyers are mediated through buying houses. Hence, enterprises depend on the putters for sampling, product development, and marketing information. This shows the division of labor between the manufacturers and the merchants or putters. The remaining 33 percent of enterprises either directly or indirectly transacts through buying houses. One of our respondents told us that they had diversified their marketing strategy in order to overcome the uncertainty associated with the orders given to them by global buyers. The marketing channels are depicted in Appendix 2.

Table 4: Marketing channel of sample enterprises

\begin{tabular}{lcc}
\hline Direct transaction & $\begin{array}{c}\text { Transaction through } \\
\text { buying houses }\end{array}$ & $\begin{array}{c}\text { Transaction directly and } \\
\text { through buying houses }\end{array}$ \\
\hline 9 & 31 & 19 \\
\hline
\end{tabular}

Source: 2011 cluster survey. 


\section{Regression Analyses}

To test the hypotheses given in Section 3, we examine the determinants of two dependent variables: (i) enterprise size through sales revenue and value-added, and (ii) the fraction of sales revenue from direct marketing through censoring. Thus, the regression equation of type would take the following form:

$$
Y_{i}=X_{i} \beta+\mu_{i}
$$

where $Y_{i}$ is a vector of observations of three dependent variables, and $X_{i}$ is a matrix of observations of the relevant set of explanatory variables such as years of schooling, operational experience, spin-offs dummy, years of marketing experience, and father's dummy (for inherited business). The parameter vector $\beta$ represents the effects that will be measured by the regression coefficients. Finally, the vector $\mu_{i}$ represents disturbances.

To test the validity of Hypothesis 1, we use the cluster-based industrial development model developed by Nam et al. (2010). If the variables representing general and specific human capital are found to be significant, it will positively affect enterprise size. We measure the size of the enterprise in three different ways to check the robustness of the model. The first measure is sales revenue, which is widely used by researchers to determine the size of an enterprise. The father's dummy variable takes the value of 1 if the entrepreneur's father was in the knitwear business and 0 otherwise. Similarly, we create a dummy variable for spin-offs, which takes the value of 1 if the entrepreneur has worked in a knitwear enterprise before and 0 otherwise. By employing sales revenue, we obtain a statistically significant schooling coefficient and highly significant coefficient on the number of years of operation of enterprises, which is the specific human capital coefficient. The other variables remain insignificant for this regression. To address the problem of heteroskedasticity in the sample, we employ the heteroskedasticity-consistent standard errors proposed by White (1980).

The second measure for the enterprise size is value-added $=$ (sales revenue - raw material cost - intermediate input cost). In the definition of value-added, we subtract raw material cost and input costs from sales revenue. The results are given in Table 5 and show that general human capital is slightly significant at around 6 percent and specific human capital is highly significant, while the remaining variables remain insignificant. This is consistent with Hypothesis 1. The third measure to determine 
enterprise size is value-added $=$ (sales revenue - raw material cost intermediate input cost - subcontracting cost). The coefficient of general human capital is significant at the 5.4 percent level and specific human capital is highly significant. The remaining coefficients are insignificant. The results are once again consistent with Hypothesis 1. So, the results are robust for three different definitions of enterprise size.

\section{Table 5: Regression estimates of enterprise size}

\begin{tabular}{lllc}
\hline $\mathbf{2 0 1 0} / \mathbf{1 1}$ & \multicolumn{1}{c}{$\ln ($ sales $)$} & $\ln ($ value-added) & $\ln$ (value-added)* \\
\hline Years of schooling & $4.35(2.14)^{* *}$ & $3.91(2.05)^{*}$ & $4.07(2.09)^{*}$ \\
$\begin{array}{l}\text { Operational } \\
\text { experience }\end{array}$ & $1.13(0.22)^{* * *}$ & $1.06(0.21)^{* * *}$ & $1.08(0.21)^{* * *}$ \\
Spin-offs dummy & $-0.21(0.43)$ & $-0.20(0.431106)$ & $-0.197(0.44)$ \\
Years of marketing & $-0.032(0.03)$ & $-0.026(0.03)$ & $-0.028(0.03)$ \\
experience & & & \\
Father's dummy & $0.24(0.45)$ & $0.18(0.44)$ & $0.20(0.44)$ \\
Constant & $4.91(6.04)$ & $5.38(5.79)$ & $4.75(5.9)$ \\
R-squared & 0.58 & 0.55 & 0.56 \\
No. of enterprises & 59 & 59 & 59 \\
\hline
\end{tabular}

Notes: Figures in parentheses are heteroskedasticity-consistent standard errors. ${ }^{* *}=$ significant at $1 \%, * *=$ significant at $5 \%, *$ significant at $10 \%$.

Value-added $=$ (sales revenue - raw material cost - intermediate input cost $)$.

Value-added $^{*}=($ sales revenue - raw material cost - intermediate input cost subcontracting cost).

Source: Author's estimates.

The variable that is highly significant in all these models is operational experience. This implies that operational experience matters and is associated with enterprise size. Enterprises grow larger over time and specifically older enterprises are larger than newer ones. It further implies that larger enterprises survive in difficult times and are able to absorb external shocks. The slight statistical significance of the schooling coefficient in the two measures of enterprise size shows that the higher level of education of entrepreneurs matters and that schooling continues to play a role. There may be a problem of an omitted variable, that of innate ability, since able entrepreneurs are more likely to attain a higher level of education, experience, and success in business operation. These human capital variables become jointly endogenous and weaken the regression results.

To test the validity of Hypothesis 2, we regress the direct transaction ratio the explanatory variables discussed above (similar to what 
was done by Sonobe et al., (2009). Since the direct transaction ratio lies between 0 and 1, we cannot employ OLS, and have to use the two-limit Tobit estimator to explain the direct transaction ratio. The results are shown in Table 6 and support Hypothesis 2 that operational experience and marketing experience are positive and significant. Finally, the father's dummy remains insignificant, which shows that having a father in the knitwear business does not have any effect in acquiring improved marketing channels. The results are shown in Table 6.

\section{Table 6: Regression estimates of improved marketing channel}

\begin{tabular}{ll}
\hline $\mathbf{2 0 1 0 / 1 1}$ & \multicolumn{1}{c}{ Estimates } \\
\hline Years of schooling & $-0.06(0.11)$ \\
Operational experience & $0.05(0.021)^{* *}$ \\
Spinoffs dummy & $-0.074(0.29)$ \\
Years of marketing experience & $0.074(0.028)^{* * *}$ \\
Father's dummy & $0.023(0.28)$ \\
Log sigma & $-0.44(0.15)^{* * *}$ \\
Constant & $0.31(1.78)$ \\
Newton Raphson maximization & 8 iterations \\
Log-likelihood & -47.39 on 8 degrees of freedom \\
Number of enterprises & 59 \\
\hline
\end{tabular}

Notes: Figures in parentheses are standard errors. ${ }^{* *}=$ significant at $1 \%,{ }^{* *}=$ significant at $5 \%$. Source: Author's estimates.

The positive and statistically significant sign of operational experience may imply that older entrepreneurs have improved operational efficiency and, subsequently, prefer to improve their marketing channels, i.e., direct transactions with global buyers to save on brokerage commissions and to obtain stable orders. Interestingly, specific operational experience plays a statistically significant role in the adoption of improved marketing channels, which is consistent with the findings of Sonobe et al. (2009). Specifically, marketing experience in merchandizing is statistically significant, which shows that entrepreneurs with marketing experience are in a better position to adopt improved marketing channels given their expertise.

\section{Conclusion, Limitations, and Future Research}

This paper has examined how enterprises innovate in developing economies by taking the suburban cluster example of Lahore in Pakistan. 
Its findings suggest that highly educated entrepreneurs with specific human capital acquired through relevant experience are associated with multifaceted innovations. It is important to mention here that the knitwear enterprises in the Lahore cluster have also benefited from opportunities that arose out of the post-quota regime. Human capital acquired through operational experience is associated with the size of the enterprise; specific human capital is associated with improved marketing channels, which help acquire stable orders.

There may be a problem of omitted variables and we cannot say for certain that the human capital variables cause the enterprise outcomes with this cross-sectional study. There is a strong association between the human capital variables and enterprise outcomes. Our findings corroborate the existing body of knowledge on enterprise performance within a cluster, and the results on Lahore may extend to other locations. However, caveats to generalizing these findings include the following: This is a cross sectional study and a pool cross-sectional and/or panel study is recommended for observing the performance of enterprises over time in order to understand the dynamics of clusters and to establish causality by addressing the omitted variable problem. Another requirement is the understanding of local socioeconomic conditions. There could also be a selection issue since the study observed surviving enterprises and we could not carry out Heckman correction due to the cross-sectional sample. 


\section{Appendix 1}

\section{Knitwear garment process flow}

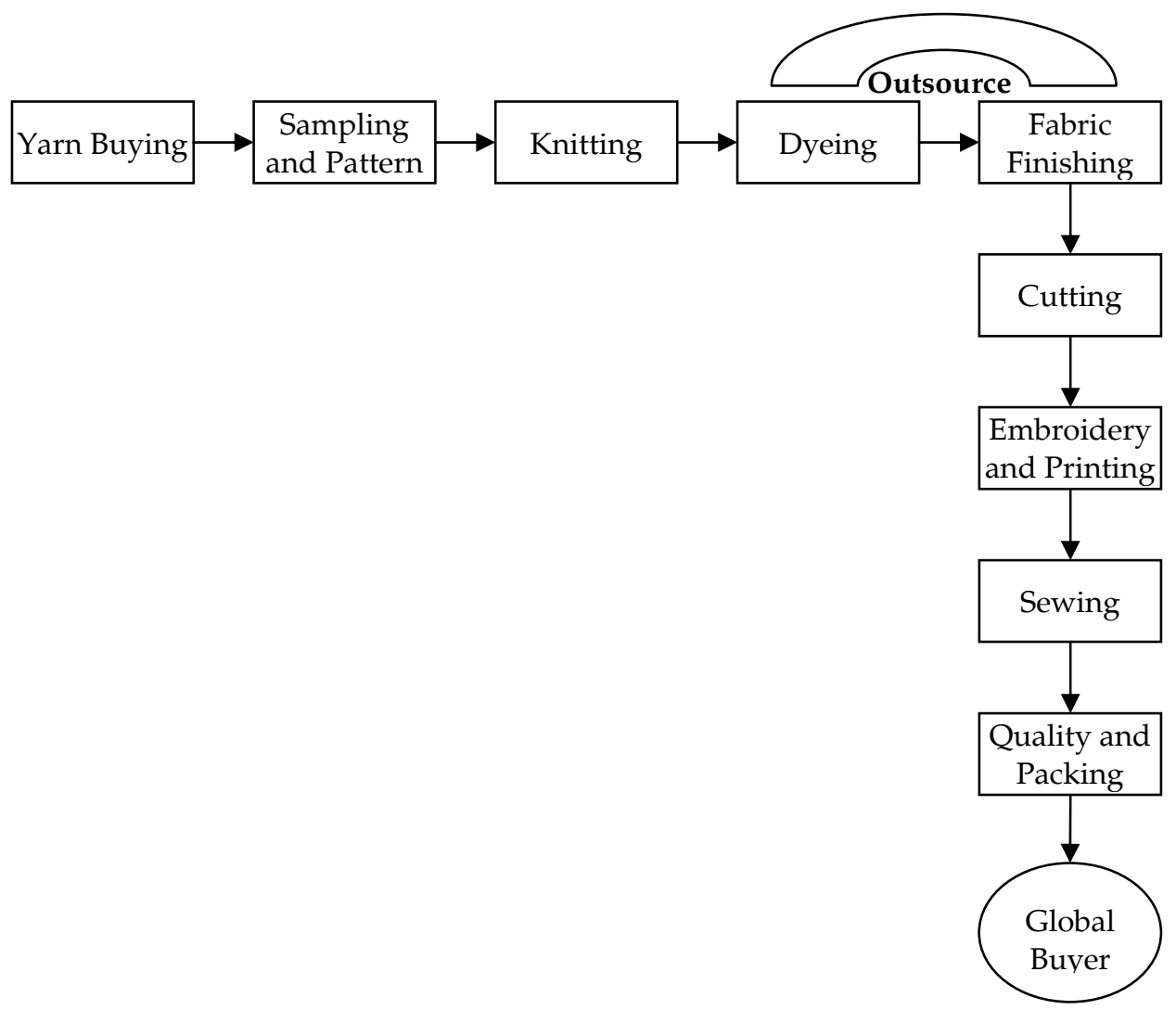

Vertical integrated enterprise: All operations from yarn buying to shipment with minor outsourcing.

Cut-to-pack enterprise: Outsourced knitting and dyeing operations, and performs the rest.

Source: 2011 Cluster Survey. 


\section{Appendix 2}

\section{Marketing channels}

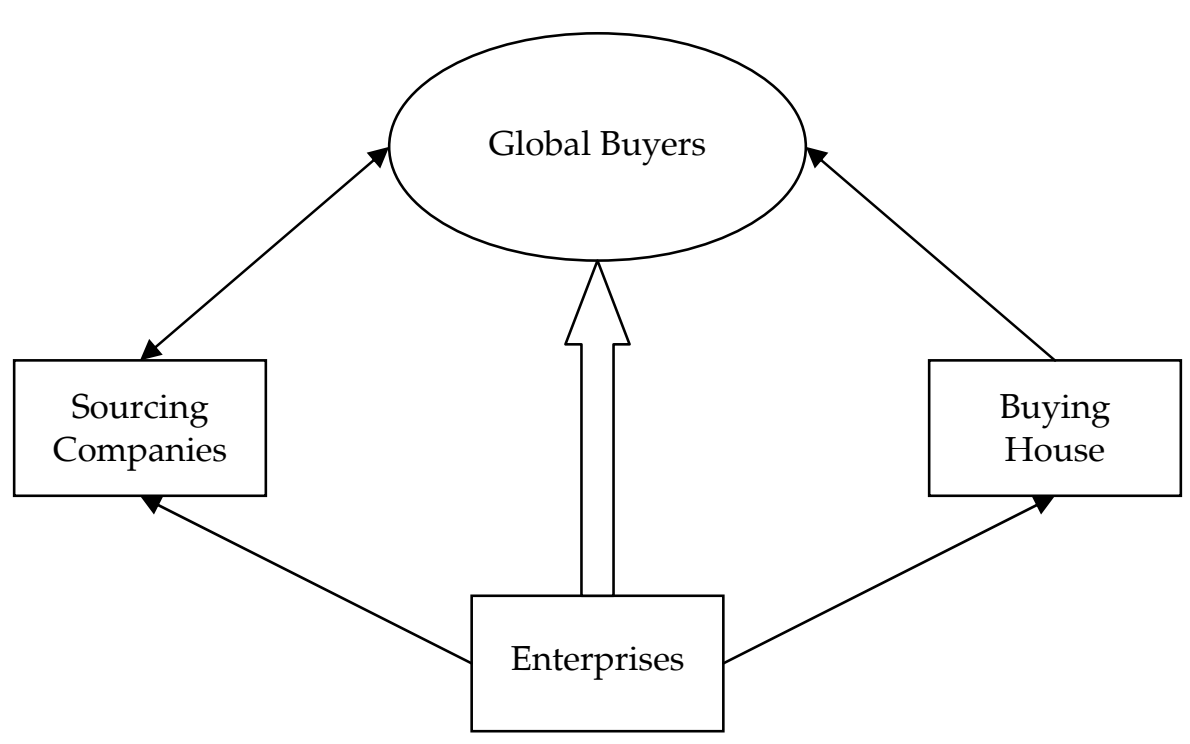

Source: 2011 Cluster Survey. 


\section{Appendix 3}

\section{Endogenous model of cluster-based industrial development}

\begin{tabular}{|c|c|c|c|c|}
\hline Stage & $\begin{array}{l}\text { Experience of } \\
\text { entrepreneurs }\end{array}$ & $\begin{array}{l}\text { Education } \\
\text { level }\end{array}$ & $\begin{array}{l}\text { Imitation, } \\
\text { innovation and } \\
\text { productivity } \\
\text { growth }\end{array}$ & Institutions \\
\hline Initiation & $\begin{array}{l}\text { Merchants/en } \\
\text { gineers }\end{array}$ & Low & $\begin{array}{l}\text { Imitate foreign } \\
\text { technology } \\
\text { directly or } \\
\text { indirectly }\end{array}$ & $\begin{array}{l}\text { Internal } \\
\text { production of } \\
\text { parts, } \\
\text { components } \\
\text { and final } \\
\text { products }\end{array}$ \\
\hline $\begin{array}{l}\text { Quantity } \\
\text { expansion }\end{array}$ & $\begin{array}{l}\text { Spin-offs and } \\
\text { entry from } \\
\text { various fields }\end{array}$ & Mixed & $\begin{array}{l}\text { Imitate imitated } \\
\text { technology: } \\
\text { stagnant } \\
\text { productivity } \\
\text { and declining } \\
\text { profitability }\end{array}$ & $\begin{array}{l}\text { Market } \\
\text { transaction; } \\
\text { division of } \\
\text { labor; formation } \\
\text { of industrial } \\
\text { cluster }\end{array}$ \\
\hline $\begin{array}{l}\text { Quality } \\
\text { improvement }\end{array}$ & $\begin{array}{l}\text { Second } \\
\text { generation of } \\
\text { founders and } \\
\text { newcomers } \\
\text { with new ideas }\end{array}$ & Very high & $\begin{array}{l}\text { Multi-faceted } \\
\text { innovations; } \\
\text { exit of many } \\
\text { enterprises; } \\
\text { increasing } \\
\text { productivity }\end{array}$ & $\begin{array}{l}\text { Reputation and } \\
\text { brand names; } \\
\text { direct } \\
\text { transaction with } \\
\text { buyers; vertical } \\
\text { integration and } \\
\text { emergence of } \\
\text { large } \\
\text { enterprises }\end{array}$ \\
\hline
\end{tabular}

Source: Sonobe and Otsuka (2006). 


\section{References}

Akoten, J. E., \& Otsuka, K. (2007). From tailors to mini-manufacturers: The role of traders in the performance of garment enterprises in Kenya. Journal of African Economies, 16(4), 564-595.

Altenburg, T., \& Meyer-Stamer, J. (1999). How to promote clusters: Policy experiences from Latin America. World Development, 27(9), 16931713.

Arif, B. W., \& Sonobe, T. (2012). Virtual incubation in industrial clusters: A case study in Pakistan. Journal of Development Studies, 48(3), 377392.

Barro, R. J. (1991). Economic growth in a cross-section of countries. Quarterly Journal of Economics, 106(2), 407-443.

Bazan, L., \& Navas-Aleman, L. (2004). The underground revolution in the Sinos Valley: A comparison of upgrading in global and national chains. In H. Schmitz (Ed.), Local enterprises in the global economy (pp. 110-139). Cheltenham, UK: Edward Elgar.

Becker, G. S. (1962). Investment in human capital: A theoretical analysis. Journal of Political Economy, 70(5), 9-49.

Becker, G. S. (1993). Human capital: A theoratical and empirical analysis, with special reference to education. Chicago, IL: University of Chicago Press.

Giuliani, E., Pietrobelli, C., \& Rabellotti, R. (2005). Upgrading in global value chains: Lessons from Latin American clusters. World Development, 33(4), 549-573.

Hackler, D., \& Mayer, H. (2008). Diversity, enterpreneurship and the urban environment. Journal of Urban Affairs, 30(3), 273-307.

Humphrey, J., \& Schmitz, H. (2002). How does insertion in global value chains affect upgrading in industrial clusters? Regional Studies, 36(9), 1017-1027.

Knorringa, P. (1999). Agra: An old cluster facing the new competition. World Development, 27(9), 1587-1604. 
Krugman, P. (1991). Geography and trade. Cambridge, MA: MIT Press.

Lucas, R. E. (1988). On the mechanics of economic development. Journal of Monetary Economics, 22(1), 3-42.

Mankiw, N. G., Romer, D., \& Weil, D. N. (1992). A contribution to the empirics of economic growth. Quarterly Journal of Economics, 107(2), 407-437.

Memon, N. A. (2010, January). Challenges faced by knitwear industry in the international export market. Pakistan Textile Journal, 56-57.

Nadvi, K. (1996). Small firm industrial districts in Pakistan. Doctoral dissertation, Institute of Development Studies, University of Sussex, Brighton, UK.

Nadvi, K. (1999). Collective efficiency and collective failure: The response of the Sialkot surgical instrument cluster to global quality pressures. World Development, 27(9), 1605-1626.

Nam, V. H., Sonobe, T., \& Otsuka, K. (2010). An inquiry into the development process of village industries: The case of a knitwear cluster in northern Vietnam. Journal of Development Studies, 46(2), 312-330.

Organisation for Economic Co-operation and Development. (2000). Links between policy and growth: Cross-country evidence (Economic Outlook No. 68). Paris, France: Author.

Porter, M. (1990). The competitive advantage of nations. New York, NY: The Free Press.

Rana, A. I., \& Khan, J. H. (2009). Achieving competitive advantage in Pakistan's knitwear garments industry. Lahore, Pakistan: Lahore University of Management Sciences.

Rosenfeld, S. (1995). Industrial strength strategies: Regional business cluster and public policy. Washington, DC: The Aspen Institute.

Saheed, H. H. A. (2011, January). What is the future of global textile and apparel industry? Pakistan Textile Journal, 54-56. 
Schmitz, H. (1995a). Collective efficiency: Growth path for small-scale industry. Journal of Development Studies, 31(4), 529-566.

Schmitz, H. (1995b). Small shoemakers and Fordist giants: Tale of a supercluster. World Development, 23(1), 9-28.

Schmitz, H. (2006). Value chain analysis for policy makers and practitioners. Geneva, Switzerland: International Labor Office.

Schmitz, H., \& Nadvi, K. (1999). Clustering and industrialization: Introduction. World Development, 27(9), 1503-1514.

Schumpeter, J. A. (1912). The theory of economic development. New York, NY: Oxford University Press.

Sonobe, T., Akoten, J. E., \& Otsuka, K. (2009). An exploration into the successful development of the leather-shoe industry in Ethiopia. Review of Development Economics, 13(4), 719-736.

Sonobe, T., Hu, D., \& Otsuka, K. (2002). Process of cluster formation in China: A case study of a garment town. Journal of Development Studies, 39(1), 118-139.

Sonobe, T., Hu, D., \& Otsuka, K. (2004). From inferior to superior products: An inquiry into the Wenzhou model of industrial development in China. Journal of Comparative Economics, 32(3), 542-563.

Sonobe, T., \& Otsuka, K. (2006). Cluster-based industrial development. Basingstoke, UK: Palgrave Macmillan.

Thompson, T. (2005). Industrial clusters in developing countries: A survey of the literature. Lahore Journal of Economics, 10(2), 15-34.

Tokatli, N. (2007). Networks, firms and upgrading within the blue-jeans industry: Evidence from Turkey. Global Networks, 7(1), 51-68.

United Nations Statistics Division. (2010). United Nations commodity trade statistics database. Retrieved 4 March 2011, from http:/ / comtrade.un.org/db/mr/daCommodities.aspx 
United Nations Industrial Development Organization. (2006). Diagnostic study: Garments cluster Lahore - Pakistan. Islamabad, Pakistan: Author.

White, H. (1980). A heteroskedasticity-consistent covariance matrix estimator and a direct test for heteroskedasticity. Econometrica, $48(4), 817-838$.

Yamamura, E., Sonobe, T., \& Otsuka, K. (2003). Human capital, cluster formation, and international relocation: The case of the garment industry in Japan, 1968-98. Journal of Economic Geography, 3(1), 37-56. 